\title{
The Rationale for Reviewing Current Concepts of Urban Planning and Developing New Ones in India*
}

\author{
A. G. Krishna Menon \\ Departments of Architecture and Urban Design, School of Planning and Architecture, New Delhi, India \\ Email: agkrishnamenon@gmail.com
}

\begin{abstract}
Urban planning in India is heir to a colonial paradigm that imposed practices developed from the experiences of Western urbanisation to the local Indian context. This paper suggests that this paradigm exacerbates the complex problems of contemporary urbanisation, but there is little attempt among Indian urban planners to acknowledge and address the consequences of their colonial legacy. The forces of globalisation are reinforcing this postcolonial intellectual malaise by reposing greater faith in capital- and technology-intensive solutions to solve problems instead of reforming the inherited processes of urban management. This paper argues that the nascent field of urban conservation in India offers the potential to review the dominant paradigms of urban planning and develop more context-specific and appropriate strategies for tackling the problems of Indian urbanisation.
\end{abstract}

KEYWORDS historic space, historic metropolitan context, evolution, reflection

Received July 5, 2017; accepted July 25, 2017.

The problems of cities in India are complex. Wages of neglect, incompetence, corruption, compounded by the consequences of uncontrolled urbanisation and rapid socioeconomic development are commonly cited as the prima facie causes for the degraded state of settlements. To many, these familiar characteristics of Indian urbanism suffice to explain the problem. It enables urban planners to absolve themselves of any responsibility for their acts of omission or commission. Nevertheless, the fact is that there are no simple explanations for the state of affairs in Indian cities. One can, however, begin by acknowledging that architecture and urbanism are neglected areas of concern in the public realm and, therefore, except for frustrated opinions and knee-jerk reactions, even the professionals and city managers seem unable to understand the deep structure of the problems confronting Indian cities. In the meantime, cities continue to function and conditions remain in the hopelessly unmanageable. Under the circumstances, one wonders whether the new, big-budget programmes for urban renewal which have recently been initiated by

\footnotetext{
* An earlier version of this paper was presented at the International Workshop on Urban Transport: Today and Tomorrow, held on March 22-24, 2007 at Agra, India, convened by the Transportation Research and Injury Prevention Programme of the Indian Institute of Technology, Delhi, India.
}

the government will be able to solve the problems of Indian cities.

Over the last decade, several mega urban renewal projects have been initiated, starting with the Jawaharlal Nehru National Urban Renewal Mission (JNNURM) in 2005 and, recently, schemes with catchy acronyms like SMART cities $^{1}, \mathrm{HRIDAY}^{2}$ and $\mathrm{AMRUT}^{3}$, along with many other lesser known schemes. It appears to indicate, at least, that there is a more concerted effort to tackle the problems of our cities. Given the starved condition of municipalities in India, these initiatives are welcome and may have some positive impact, but, in the main, I remain sceptical because these initiatives are attacking the symptoms of the failures of city planning and not the planning process itself which, I believe, is causing the problem. The Indian Institute for Human Settlements points out that 'nearly 40 per cent of urban households do not have access to treated tap water and around 13 per cent still defecate in the open' (IIHS 2015). Hi-tech initiatives for street lighting or monitoring water supply, as these urban renewal schemes tend to favour, fail, first, to tackle the most basic civic needs and, second, to reform the planning paradigm that creates these problems in the first place. For instance, the New Delhi Municipal Corporation-catering to one of the 
country's richest municipalities - was the easy recipient of a SMART City grant, while Delhi's many proliferating slums do not fall within the purview of the scheme. The massive urban renewal initiatives are one of the consequences of the increasing influence of globalisation. After all, if India aspires to be counted among the advanced societies in economic and technological terms, how can its cities present a contrary picture? What is fuelling the strategies to transform cities is therefore massive infusion of capital and technology. Interestingly, however, one of the consequences of the infusion of global strategies of change has been the catalysing of a greater interest in the traditional practices the new vision seeks to replace. At a recent conference convened by ICOMOS India at Bengaluru, India ${ }^{4}$, for example, the saliency of traditional knowledge systems of building and the continued relevance of historical precincts in the functioning of modern cities was discussed. Participants highlighted the fact that in certain societies (like India), concepts of history and memory that underpin the continuities of urban living cannot be easily dismissed because they still mediate the lives of citizens and redefine the nature of the modernisation processes underway.

A few days later, at another conference, this one on vernacular architecture, held at the School of Planning and Architecture, Bhopal, India ${ }^{5}$, the relevance of vernacular architectural practices to meet the needs of the fast-growing habitats in India was discussed. Participants from different disciplines from all over India agreed that modern construction practices were not able to meet the tremendous demands for new habitats created by the massive urbanisation taking place in the country and that building policies needed to be purposefully redirected to promote the living traditions of vernacular architecture that were still in use all over the country. Moreover, it was highlighted that these practices were also environmentally and culturally more appropriate. The delegates unanimously adopted a Charter to promote the practice of vernacular architecture as an appropriate strategy to modernise Indian architecture and cities.

These conferences are examples of the concerns being expressed among many architects, urban planners and scholars working in developing countries on the inadequacy of adopting methods and strategies of planning and building that are based on the experiences of modernisation in Western countries. They are beginning to realise that, perhaps, new and culturally rooted process, must be relied upon to deal with overwhelming urban and spatial problems of the developing countries. There is, therefore, an increasing interest in examining what may be termed 'indigenous' approaches to deal with urban and architectural issues in many societies around the world. This paper examines the rationale of this perspective in the Indian context.

The correlation between urbanisation and economic development is a well-established universal phenomenon. It is, therefore, predictable that in India, the dramatic growth of the economy will fuel massive urbanisation. Even as city administrations try to cope with the current level of urbanisation (31.16\% according to the 2011 Census), they will have to deal with far greater volumes of migrants in the future (The Planning Commission of the Government of India, for example, expects the urban population to double in the next 25 to 30 years). But the issue of urbanisation is not just a matter of numbers, because these numbers are also characterised by the increased complexity of the phenomenon. We are beginning to realise that existing models of urban planning-primarily based on the experience of urbanisation that took place in the West during the last century-addressed a simpler order of complexities and dealt with fewer numbers of migrants to cities and therefore they are unable to cope with the emerging understanding of the multifaceted nature of the country's urbanisation phenomenon.

Some of the characteristics of the problems that are being created by urbanisation in countries like India were studied by the Asian Coalition for Housing Rights (ACHR), Bangkok, which undertook research in eight Asian cities to identify the process of socioeconomic, physical and institutional changes that had taken place since the late 1980s (Satterthwaite 2003) ${ }^{6}$. These changes occurred on account of the structural adjustments imposed by the conditions imposed on account of the process of globalisation such as the institutional regime required by World Trade Organization (WTO). The ACHR report documented how the WTO conditionalities adversely affected the lives of local urban residents, particularly of disadvantaged groups, and pointed to the need to develop appropriate urban planning and governance strategies to mitigate its negative effects.

As the global economic networks strengthen and the Indian economy becomes more integrated into it, the situations documented in ACHR's report are becoming more manifest in Indian cities. For example, the increasing fragmentation of cities into segregated zones of the rich and poor have become more evident. Cities in India have, of course, always evolved along lines of caste and class, but the new patterns of change identified in the report involve 
a far greater scale of spatial segregation and a more complex combination of social and economic factors which did not exist before. For example, the new economic and political policies are uprooting the poor and middle class from the land they had occupied in or near city centres of historic cities. They are frequently offered no compensation or are relocated, formally or informally, to areas on the city's fringes, far away from their places of work, education and recreation and with inadequate access to civic infrastructure or health services. Such processes threaten the social, cultural and political fabric of society and, ultimately, its stability, as the unequal distribution of civic resources leads to popular unrest and violent confrontation as have been witnessed in not only India but many other parts of the world as well. The profession and discipline of urban planning in India has not yet begun to comprehend, let alone develop, appropriate strategies to handle this consequence of economic development even as it embarks on urban renewal projects like SMART cities that will, predictably therefore, exacerbate existing problems. This failure is rooted in the history of the profession in India.

Civilisational continuities are manifest at several levels and forms in Indian society, but these traces are often elided in trying to understand or deal with the modern urbanisation phenomena. While it is known that there were vibrant urban civilisations in India and town planning had been practiced here for millennia, it is commonly accepted that with colonisation, these practices were wiped out and replaced by European models and processes. This shift in the planning paradigm was understandable during the colonial period but, unfortunately, its significance eludes the imagination of the contemporary Indian urban planning profession, and even 70 years after Independence the colonial imperatives continue to define official practices. In this paper I analyse the epistemology of modern urban planning in India, in order to throw light on our current planning predicament and the need to reconsider the consequences of this historic process by focusing on the relevance of indigenous urban planning and architectural perspectives.

The modern practice of urban planning in India was initiated after the War of 1857 . The British realised that they had come within a hair's breadth of losing their empire in urban areas because the organic morphology of Indian cities and towns made them difficult to control. There was a concerted effort thereafter to rebuild Indian towns on more familiar terms that they could 'understand'. In her book, Making of Colonial Lucknow, 1856-1877, Veena Talwar Oldenburg (1984) compellingly demonstrated the imperialist logic that underpins the legacy of modern urban planning in India and, indeed, by extension, of the understanding of modernity itself.

Arindam Dutta in The Bureaucracy of Beauty (Dutta 2007) makes another crucial point. According to him, on account of the colonial influences, the process of making a plan or designing a 'solution' to urban 'problems' is already predetermined by the architect or urban planner before understanding the specifics of the situation at hand. Not surprisingly, such plans fail to meet the actual needs of local societies and are frequently resisted, subconsciously or explicitly, by local inhabitants who must bear the brunt of these ill-conceived 'solutions'. Today, therefore, the situation has come to such a pass that in order to establish the authority of its Master Plans, the government has to deploy the police powers of the State to 'enlighten' society and compel its acquiescence to ensure that 'solutions' are duly implemented. Dutta's argument helps explain the process of sealing and demolition of 'illegal' buildings that is frequently undertaken by the government in many parts of Delhi because these buildings do not conform to the legal prescriptions of urban planning and building bylaws-a process that has transformed affected parts of the city to look like war zones. The destruction they wreck is rationalised by urban planners (who created the problem) and bolstered by the judiciary (who only consider it as a legal issue) as a cost that society must bear in order to 'modernise' and institutionalise urban planning practices. As Dutta says, 'It is because the origins of modernity in the colony are inexplicably tied up with the ends of imperialism that its outlines operate as a historical teleology in reverse: first the institutions and then the "enlightenment".

An example of how the 'modern' process of planning was institutionalised is The Handbook on Town Planning first published by the Public Work Department (PWD) in 1876 (Talim 1976). The Handbook contained guidelines for undertaking urban development projects all over the country and it is easy to trace the origins of many current professional philosophies and practices to this book. These guidelines were formulated at a time when the British had begun systematic efforts to ensure civic health and hygiene in their own cities at home, so they merely transferred the models they had developed for British cities to the colonies. Nevertheless, their desire to incorporate new ideas was evident even then, because the Handbook was updated eight times in the 70 years before Independence, with each successive edition including the latest British advances in urban planning practice. In all the decades since Independence, however, the Indian PWD, the heir 
to this legacy, republished the Handbook only twice and did not attempt any major changes to its contents. Thus the dated references to Ebenezer Howard's Garden City and the New Town plans developed in the UK between the two World Wars are retained as models to be used in India. While it is possible that the irrelevance of the Handbook's contents has led to its natural abandonment as a guide, it is very clear that its ideas have nevertheless deeply moulded the imagination of the Indian urban planner. In fact, its lingering presence in current practice illustrates two debilitating characteristics of urban planning in India: first, the unthinking acceptance of foreign models to serve local purposes; and second, the inability, or unwillingness, among professionals to update their knowledge base and intellectually engage with the specific complexities of Indian urbanism both as a socio-cultural construct and as a technical entity. Instead, contemporary Indian urban planners ape the colonial British in the original desire to protect their empire by disciplining the native urban space and punishing its 'disorderly' manifestations which were assumed to be the expressions of a rebellious populace. So deeply embedded is this punitive vision, that the notion of a planning model that mediates and facilitates the process of urbanisation and that is sensitive to the needs of vast swathes of disadvantaged inhabitants becomes tragically inconceivable.

Massive urbanisation is transforming Indian cities. Economists consider this process necessary to develop the country. Sociologists also believe that the changes it brings to social values are essential for modernisation. But urban planners treat the phenomenon as a 'problem'. They want to restrict growth of cities and 'control' it-which, in fact, translates to 'impede'-its development. However, the growth and expansion of cities follow a logic which, as is becoming increasingly apparent, works in defiance of the visions of urban planners. Nowhere is the consequence of this tragic misunderstanding more evident than in the manner in which planners have dealt with-or neglected-historic cities.

There are hundreds of historic cities in India which continue to provide humane habitats to those who live in them. But they are all under pressure to change due to the processes of modernisation, and imposition of modern forms of development. Thus the continued vitality of cities like Madurai and Varanasi, for example, challenges the rationale underpinning the prevalent planning ideology. These cities are transforming, but there is a message embedded in the transformation taking place that escapes the attention of planners. Lewis Mumford alluded to this process when he said historic cities represent 'energy converted into culture' (Mumford 1961). Diana Eck refers to it when she points out that, in the case of Varanasi 'there are a few great cities in the world which have converted the energy of an entire civilisation into culture, and come to symbolise and embody that whole civilisation in microcosm'. She adds, '[Varanasi] is not an easy city to comprehend for those of us who stand outside the Hindu tradition. As we survey the riverfront at dawn, we are challenged to comprehend the whole of India in one sweeping glance' (Eck 1984, 5-6).

It is not my case that we stand within Hindu tradition to understand Varanasi, but rather that urban planners need to understand the nature of the 'energy' that enables historic cities like Varanasi and Madurai to continue as vibrant habitats in contemporary circumstances. This 'energy' has enabled them to face the challenges of Indian urbanisation and evolving urbanism with a dignity and grace that eludes modern cities. Perhaps, understanding how such historic cities negotiate urbanisation holds the key to mediate the future of Indian cities. The ICOMOS conference I mentioned earlier sought to explore this perspective.

But it is difficult to turn the gaze of urban planners towards these cities. Today, in the conditions they are in, most historic cities seem to offer no hope. Not surprisingly, planners are captivated by the image of modern cities in economically and technologically advanced societies and seek to use them as templates to solve the problems of the old cities in developing societies. The denigration of local historic cities by Indian planners mimics that of Western scholars who measured Indian cities by the yardstick of Western ones and found the former deficient in comparison to their own cities. For example, according to Fernand Braudel (1992, 509), 'Every Muslim town was an inextricable network of badly maintained lanes.' In her study of Shahjahanabad, Shama Mitra Chenoy (1998) observes that Perry Anderson 'found the raison d'être and the destiny of cities in Asia subject to the "whims" and "fancies" of the princes'. She quotes Anderson (1998, 4): 'Consequent to their pattern of hasty settlement and desolation, Islamic cities lacked any coherent internal structure, whether administrative or architectonic. They are confused amorphous mazes of streets and buildings, without public centres or spaces; focussed only on mosques and bazaars and the local trades huddled around them. Grown in disorder, lacking plan or charter, the fate of Islamic cities was normally determined by that of the state whose fortunes had conferred their prosperity on them.' In this manner, the 
remarkable qualities of old cities are not only ignored, but disparaged.

The failure to understand the forces of indigenous urbanism continues. Even in 1924, when the Imperial government was building New Delhi, government records about the construction in progress identified the problem of local developments not following the Master Plan formulated by Edwin Lutyens. As Stephen Legg $(2006,4)$ observed in his study of Delhi's postcolonial development, 'the would be panopticism of the imperial city became impossible to regulate from the very beginning'. A 1939 report that Legg cites, reproduced the 1914 sanctioned layout of New Delhi-a map of stark and clearly defined functional zones-and contrasted it, equally starkly, with a map of the actual layout of New Delhi which, by 1938, illustrated a dazzling array of mixed land-uses and what to the official gaze were 'haphazard developments'. Even then the problem was not identified as one of supply and demand or of the need to understand local characteristics of urban living; then, as today, it was perceived to be one of the lack of strict regulation. Thus the main recommendations of official reports he cites invariably reinforced the imperative to regulate development so that it conformed to official plans. In subsequent post-Independence government policies, stricter enforcement of the law has remained the leitmotif of recommendations to solve the persistent problems of 'illegal' development. Indeed, this collective fixation with enforcement on the part of both urban planners and government policymakers-so that the issue is seen as one of law and order rather than that of inadequacies in the planning process itself-is arguably the most significant obstacle to contemporary India urban planning.

Legg identified another significant dimension of the problem of urban planning in India: urban planners deal with the city as an abstract entity rather than as a living organism. Consequently, there is no intellectual or moral commitment to the plans that they make-merely a feeling of victimisation when inhabitants do not follow their prescriptive abstractions. Perhaps this professional indifference to the socio-spatial consequences of their policies is also rooted in the Nehruvian development paradigm that sought to combine the existing capitalist system with a Soviet-inspired model of centralised economic planning. In the Nehruvian paradigm, planning was a 'scientific' process, the domain of 'objective experts', its goal the furtherance of national interests (which, presumably, would trickle down as local benefits). The aim was to rule 'from a distance' by targeting supposedly discrete, self-contained and static objects such as an economy or a population. Post-Independence urban planning is deeply rooted in the ideology of planning 'from a distance"

Regrettably, urban planners seem to be the last to realise that cities are neither abstract nor static entities and that unless they seriously engage with the specific ground realities of Indian urbanism (often displaying characteristics of pre-colonial spatial propensities), the profession will not be able to cope with the fact and type of contemporary development problems documented in the ACHR report ${ }^{8}$. The force of this tragedy has manifested itself time and again, as for example with the developments undertaken for the Commonwealth Games held in Delhi in 2010. With a view to 'impressing the world', the government had embarked on a series of ill-advised, costly and unsustainable projects such as urbanising the ecologically fragile flood plains of the Yamuna river and undertaking 'tourist-friendly' beautification projects which did nothing to resolve the day-today spatial problems that plagued the city's inhabitants. In a similar vein, the current government is embarking on a very ambitious and costly exercise to build 100 'SMART Cities' in the naïve expectation that they will be the answer to the country's urban problems (Figure 1).

Clearly, there is an urgent case to be made for changing the way urban planners conceive urban space. This, in turn, requires a comprehensive reformulation of our disciplinary assumptions and pedagogic practices. At present our academic institutions emphasise the rote transmission of received knowledge and routine methods for minimally informed and vocational ends. Unsurprisingly, there is little or no local theorising of the urban planning experience in India. By habit and circumstance local urban planners have accepted images of cities derived from cultural, social and economic contexts different from theirs and recycled them into teaching curricula. In this light the policy to build 'Smart Cities' is not surprising. The situation cannot change unless practitioners undertake focused studies of Indian cities based on innovative hypotheses that challenge received wisdom. Such research would enable urban planners to conceive Indian cities in indigenous terms in order to incorporate the culturally plural, socially evolving and economically constrained characteristics of Indian society. They need to critically interrogate the mentality represented by the PWD Handbook in order to decolonise the prevalent concepts of Indian cities.

The exercise to analyse the intellectual and sociopolitical history of urban planning in India and to thoughtfully chart parameters for contemporary practice, must regard cities as human spaces in which rational 


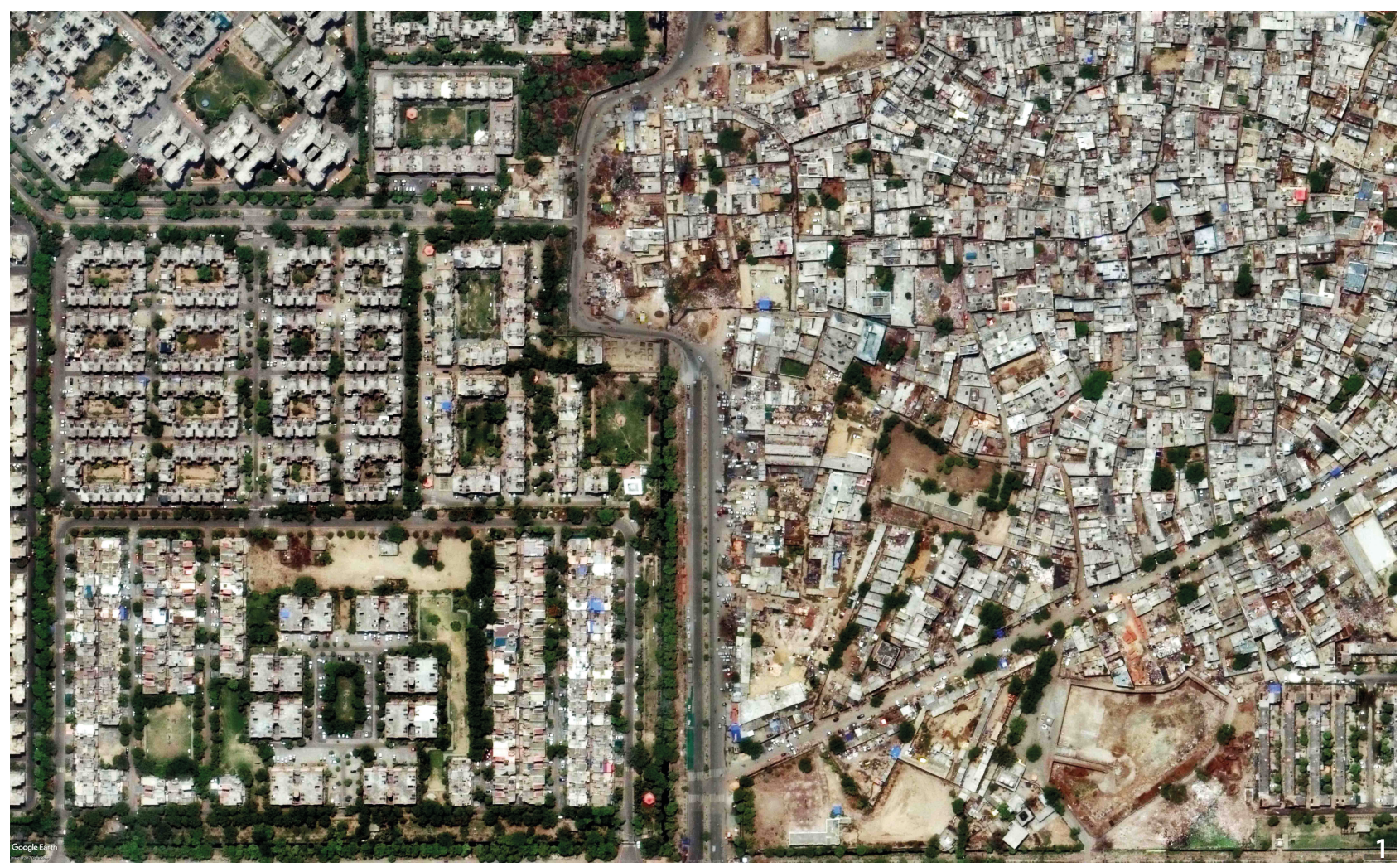

Figure 1 Aerial view of new developments near Delhi, showing informal settlements competing for space against the planned settlement. Such contestations are common in most Indian cities raising questions about appropriate strategies to adopt to cater the needs for rapid urbanisation (Source: image from Google Earth on August 30, 2017).

people live and participate rather than by alien and unruly objects that must be tamed with the urban planner's objective expertise. Instead of perennially viewing what exists locally in negative terms and using Western standards as positive benchmarks, urban planners in India must understand that their inherited and supposedly neutral urban planning practices are driven by a logic of aggressive and purposive control of the population'. This new vision must be one that fosters social welfare rather than one which relies on punitive sanctions in single-minded service of the abstract patterns on paper which they call Master Plans. The current historical condition demands that the existing planning paradigm be cast aside; changing the way planners conceive the city is an important beginning in this process: the conferences I mentioned at the beginning were steps in that direction.

It is pertinent to note that most of the books and studies that I have cited in this paper are by scholars based at research institutions abroad. As I have already mentioned, we must restructure our curricula and pedagogy in order to locally develop appropriate urban planning strategies to deal with local urban conditions. Lest I be misunderstood, I do not propose a simplistic - and flawed - distinction between foreign and local research; rather, I encourage context-specific research generated in Indian institutions as a key component of a dynamic indigenous urban planning practice. In other words, my concern is not with the 'foreignness' or 'localness' of research per se, but rather with the presence (or absence, in our case) of a critical intellectual sensibility, academic tradition and professional practice that can make an informed and compassionate intervention in the way our urban spaces are structured and lived today.

But where do we begin? In challenging our wholesale adoption of Western planning ideologies, I do not mean to advocate an equally problematic embrace of all ideologies Indian. Again, the key is not simply to reject or accept all material from this or that source or historical period, but rather, to inculcate a particular critical intellectual attitude towards all our disciplinary traditions and practices. So, for instance, ancient Indian theological treatises and commentaries are not automatically relevant to our modern context just because they are Indian. Similarly, pre-colonial literature on cities and towns is also of only limited use because it is characterised mostly by biographical writings, which do not provide critical analysis of towns (Misra 1981). We must distinguish between biographies and focused studies based on explicitly formulated hypotheses. 
It is only this latter, critical perspective that allows us to begin to understand the nature of the Indian city, the dynamics of its institutions, the contours of its socialpsychological makeup and the ethos of its urban classes. There have been few such attempts to understand the complexity of the urban condition in India with the major exception of the 1988 Report of the National Commission on Urbanisation (NCU) (Government of India 1988). But the NCU Report is a largely forgotten exercise today.

To begin, therefore, one could continue from where the NCU Report left off in 1988. The Report took into account the singularity of the Indian urban condition, which derives from the fact that Indian society has widely plural characteristics, temporally, culturally, and economically. By and large, such conditions do not exist in other societies, old or new, and while we may gain insights through cross-cultural references on certain issues, it does not eliminate the need to do our own homework. In urban planning terms, in India, not one, but several disparate circumstances need to be reconciled simultaneously: neat suburban developments with homogenous populations and the persistence of the heterogeneous 'chaotic' traditional settlements; the city of the 'haves' and the city of the 'have-nots'; Lutyens' baroque city and the qasba; the automobile, the bicycle and the hand-cart, etc. There are few models available anywhere with which to conceptualise such heterogeneity, so town planners in India will have to become increasingly self-referential. Notwithstanding the problems and pitfalls inherent in capturing this changing perspective, there are promising avenues that can be fruitfully explored.

One such area of enquiry lies in the field of urban conservation. With the establishment of the Indian National Trust for Art and Cultural Heritage (INTACH) in 1984, there was a focused interest in the conservation of our built heritage. It soon became clear that the dominant Western conservation practice-that sought to maintain museum-like conditions-could not be a viable model for India and that we would have to view our heritage in developmental terms. This was the underlying premise of INTACH's 'Heritage Zone' concept. There is reason to believe that this concept has a wider application (Menon 1989). INTACH's projects demonstrated that a study of traditional settlements with a view to developing them offered an appropriate strategy for urban planners to plan or renew other parts of the city as well. Such a perspective will inevitably force modern urban planners to abandon the Handbook approach and focus on the particularities of the built-up areas within towns. These pre-colonial parts of the city have so far been neglected by civic authorities, academics, policymakers and town-planners. However, these traditionally evolved settlements are the repositories of culturally embedded methods and devices of urban planning which, rooted as they are in local material and social culture, offer valuable insights for planning contemporary cities (Menon 1989). Inter alia, it offers a potentially productive strategy to explore indigenous approaches to urban planning and architectural issues (Figure 2, Figure 3).

Having worked with INTACH on conservationoriented development proposals for historic cities such as Varanasi, Ujjain, Old Bhubaneswar and Chanderi, I can state with a certain degree of confidence that the apparently intractable urban problems can be resolved ${ }^{10}$. Almost a century ago Patrick Geddes had already convincingly demonstrated that this was possible in a manner that the modern town planner needs to re-examine. Geddes regarded the city as an organic system that was amenable to a carefully structured process of 'healing and natural growth'. His approach was context-specific and, as such, it was both locally effective and satisfactory (Tyrwhitt 1947) ${ }^{11}$. The urban conservation projects that INTACH undertook were also, by their very nature, contextspecific. They required us to look closely at the origins of specific local problems in order adequately to understand their particular characteristics. This process enabled us to develop responses tailor-made for the issue at hand rather than struggling clumsily and autocratically to impose predetermined solutions derived from inappropriate contexts. This did not mean that there were no overarching objectives guiding our work. We accepted, for example, such broad objectives as the need to improve the quality of life at the local level, achieve sustainable development at the social level and a 'people-first' approach to problemsolving in general. Of course, there were other specific issues too, such as accepting the evidence of tradition as the norm, but suffice it to say that this was a different way of conceiving the city in terms of settlement density, social heterogeneity and economic mix than what we had been academically trained to pursue. These historic cities possessed an urban character not seen in those other parts of the city developed by modern town planners. While they had real problems - such as infrastructural inadequacies and other forms of deprivation-as urban typologies they were both satisfying and appropriate models for reimagining the Indian city. What emerged in our work was the possibility of creating what Robert Venturi (1966) terms a 'both-and' environment and the lesson we learnt was that this condition is, in fact, the deep structure of Indian 


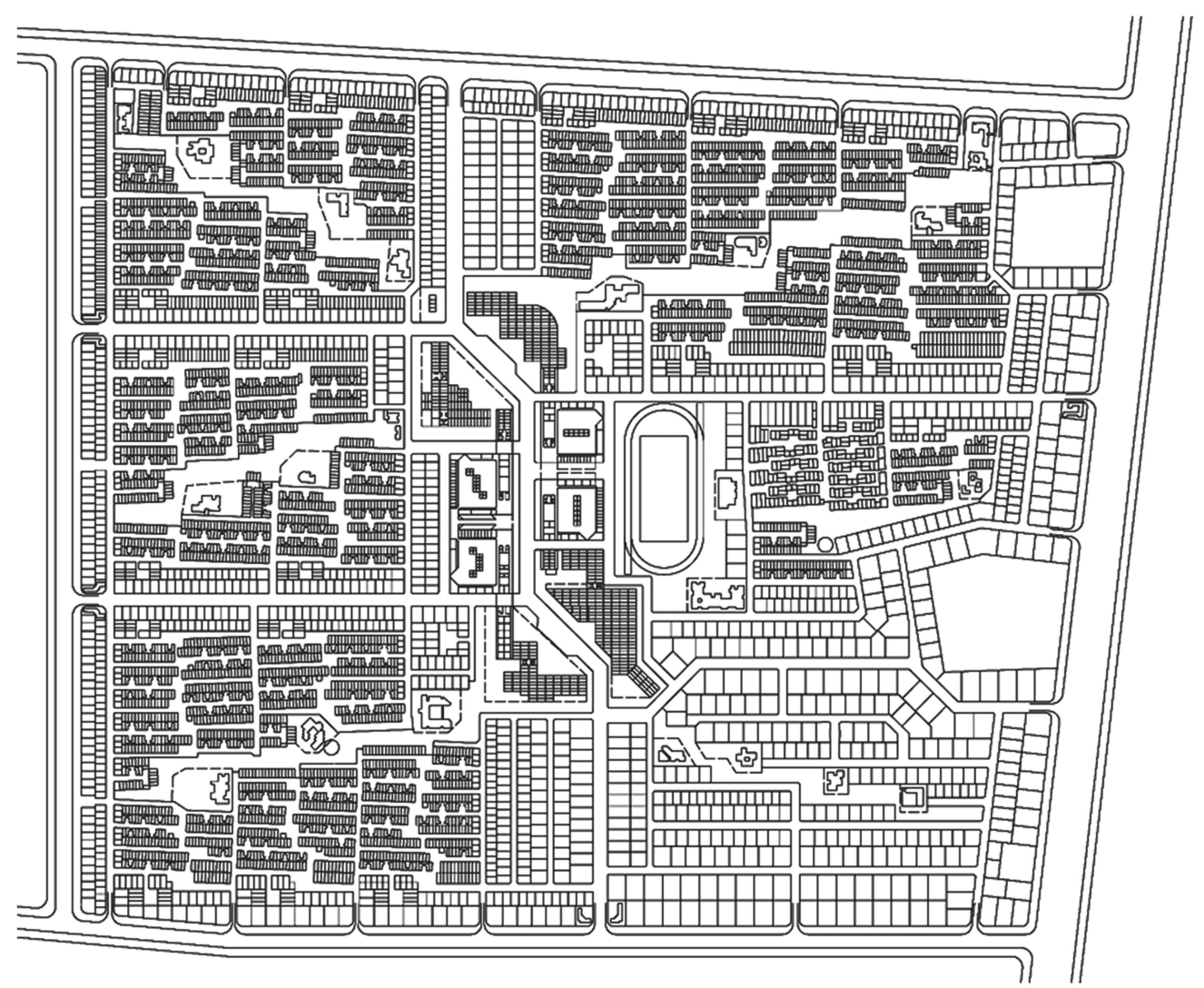

Figure 2 Envisaged Built form: Essentially a low rise high density development, the built form echoes the traditional fabric with continuity of built edge, shared walls, favourable micro climate, house form variations and cultually appropriate settings. Typical example of non-Western urban planning Aranya Community Housing, Indore, Madhya, Pradesh. Architect: B.V. Doshi (Source: The Aga Khan Award for Architecture 1995).
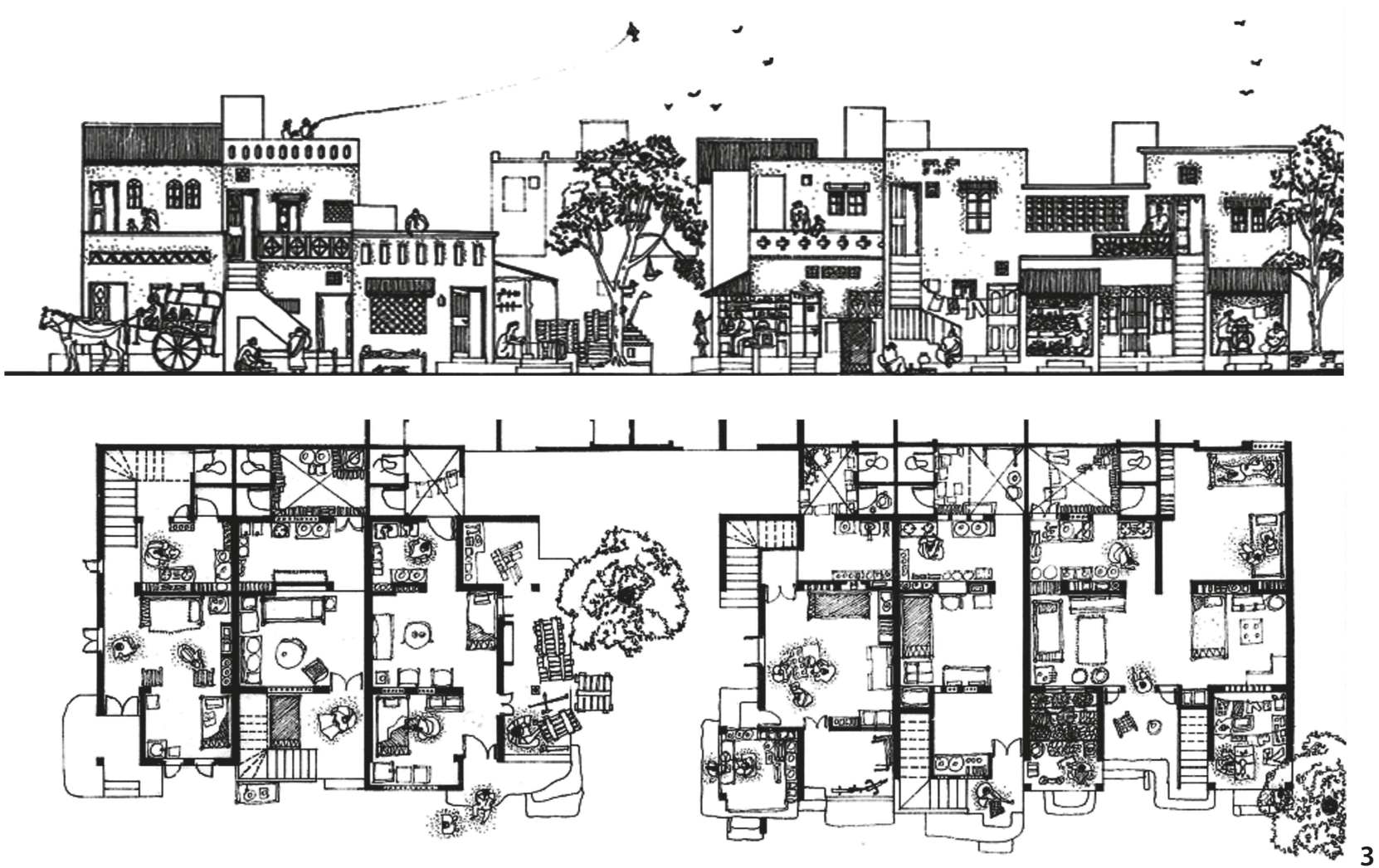

Figure 3 Example of street Elevation (up) and plan (below) of the Aranya community housing, Indore, Madhya Pradesh (Source: https://www. slideshare.net/khushboosood/aranya-community-housing). 
urbanism which has been obscured by modern urban planning practices ${ }^{12}$.

This understanding suggests that urban habitats in India need multiple strategies-and not a singular Master Plan-to meet the ends of achieving satisfying living environments for the variety of their inhabitants. The moral imperative, I argue, is for an equitable and contextspecific model of urban governance rather than a merely uniform Master Plan derived from Western priorities and experiences. The Heritage Zone concept that I have mentioned earlier offers a potent example of this model: it requires urban planners to focus on local urban histories and contemporary development dynamics at play in that area that necessarily get elided in the top-down implementation of Master Plans.

When such views are presented to urban planners at the helm of affairs, their characteristic response is they necessitate radically new ways of town planning practice that are legally, practically and politically unfeasible. As enthusiasts of unbridled globalisation and proponents of the 'India Shining' brand of urban development, these urban planners strenuously contest the aesthetics of 'bothand' environments. Ironically, however, it is exactly such a radical 'both-and' aesthetic that underpinned the Jawaharlal Nehru National Urban Renewal Mission (JNNURM), which aimed to put into practice the principles enunciated in the $73^{\text {rd }}$ and $74^{\text {th }}$ amendments to the Constitution of India that mandate a radically different, decentralised planning and development process. JNNURM targeted 63 cities for renewal. But the Mission failed and has been replaced by the 'Smart Cities' programme. If urban planners have the courage to re-evaluate their professional legacy and contemporary obligations and to seize the opportunity presented by urban conservation, the JNNURM and the NCU Report and engage with context-specific approach to urban and architectural issues, then they could usher in long-overdue and far-reaching changes in the way urban planning is practiced in India. It is only through such changes that the profession will be able to engage meaningfully with the complexity of Indian urbanism.

\section{Notes}

1. The Smart Cities Mission was launched by the Government of India's Ministry of Urban Development in 2015. See: http://smartcities.gov.in/content/ (accessed June 28, 2017).

2. The National Heritage City Development and Augmentation Yojana was launched by the Government of India's Ministry of Urban Development in 2015. See: http://hridayindia.in (accessed June 28, 2017).

3. The Atal Mission for Rejuvenation and Urban Transformation was launched by the Government of India's Ministry of Urban Development in 2015. See: http:// amrut.gov.in (accessed June 28, 2017).

4. ICOMOS, $12^{\text {th }}$ Annual Meeting and Scientific Conference for Theory and Philosophy of Conservation and Restoration, November 26-28, 2015, Bengaluru, India.

5. Conference on South Asian Vernacular Architecture held on December 11-13, 2016 at the School of Planning and Architecture, Bhopal, India.

6. The cities studied were: Beijing (China); Pune (India); Chiang Mai (Thailand); Phnom Penh (Cambodia); Karachi (Pakistan); Muntinlupa (Manila, Philippines); Hanoi (Vietnam); and Surabaya (Indonesia).

7. It is often assumed that it is difficult to understand a Third World metropolis. The truth is that this has rarely been attempted. An attempt by the World Bank might serve as a useful model (Mohan, 1994).

8. For greater insights into this process see Myrdal (1968).

9. Even the chapter titles of her book make for an insightful commentary on the contemporary imperatives of town planners: 'The City Must Be Safe' (where she discusses demolitions and the building of segregated enclaves); 'The City Must Be Orderly' (the disciplining role of the police and the Municipal Committee); 'The City Must Be Clean' (sanitation and building byelaws which changed the morphology of the city and, hence, its social livability); 'The City Must Pay' (the concept of penal tax); and 'The City Must Be Loyal' (the making of a loyal elite) (Oldenburg 1984)

10. Unpublished reports available upon request at the Indian National Trust for Art and Cultural Heritage, 71, Lodi Estate, New Delhi, India.

11. For an interesting commentary on the issue of context specificity, see Ramanujam (1989).

12. Indeed, one is tempted to paraphrase Venturi's oftquoted comment on the Main Street: 'Traditional cities are almost always alright!'

\section{References}

Anderson, Perry. 1974. Lineages of the Absolutist State. London: New Left Books.

Braudel, Fernand. 1992. Civilization and Capitalism: 15th18th Century, Volume I: The Structures of Everyday Life; The Limits of the Possible. Translated and edited by Siân Reynolds. Berkeley \& Los Angeles: University of California Press. 
Chenoy, Shama Mitra. 1998. Shahjahanabad: A City of Delhi 1638-1857. Delhi: Munshiram Manoharlal Publishers.

Dutta, Arindam. 2007. The Bureaucracy of Beauty: Design in the Age of Its Global Reproducibility. New York: Routledge.

Eck, Diana L. 1984. Banaras: City of Light. London: Routledge \& Kegan Paul.

Government of India, Ministry of Urban Development. 2017. Atal Mission for Rejuvenation and Urban Transformation. Accessed June 28 2017. http://amrut.gov.in

Government of India, Ministry of Urban Development. 2017. National Heritage City Development and Augmentation Yojana. Accessed June 28 2017. http://hridayindia.in

Government of India, Ministry of Urban Development. 2017. Smart Cities Mission. Accessed June 282017. http://smartcities.gov.in/content/

Government of India, National Commission on Urbanisation. 1988. Report of the National Commission on Urbanisation, Volumes 1 and 2. New Delhi: Government of India Press.

IIHS (Indian Institute for Human Settlements). 2015. Urban India 2015: Evidence. Bengaluru: Indian Institute for Human Settlements.

Legg, Stephen. 2006. "Post-Colonial Develop-mentalities: From the Delhi Improvement Trust to the Delhi Development Authority." In Post-Colonial Geographies of India, edited by Saraswati Raju, M. Satish Kumar and Stuart Corbridge, 182-204. New Delhi: Sage Publications.

Menon, A.G. Krishna. 1989. "Conservation in India: A Search for Directions." Architecture+ Design, November-December.

Menon, A.G. Krishna. 1989. Cultural Identity and Urban Development. New Delhi: INTACH.

Misra, S.C. 1994. "Urban History in India: Possibilities and Perspectives." In The City in Indian History: Urban Demography, Society and Politics, edited by Indu Banga. Delhi: Manohar Publications.

Mohan, Rakesh. 1994. Understanding the Developing Metropolis: Lessons from the City Study of Bogota and Cali, Colombia. Washington, D.C.: The World Bank.

Mumford, Lewis. 1961. The City in History: Its Origins, Its Transformations, and Its Prospects. New York: Harcourt, Brace \& World, Inc.

Myrdal, Gunnar Myrdal. 1968. Asian Drama: An Inquiry into the Poverty of Nations. New York: Pantheon.

Oldenburg, Veena Talwar. 1984. Making of Colonial
Lucknow: 1856-1877. Princeton: Princeton University Press.

Ramanujam, A.K. 1989. "Is there an Indian Way of Thinking? An Informal Essay." Contributions to Indian Sociology (new series) 23(1): 41-58.

Satterthwaite, David. 2003. Understanding Asian Cities. Bangkok: Asian Coalition for Housing Rights.

Talim, B.T. 1976. “Town Planning.” Chap. 2 in PWD Handbook. 16th ed. Bombay: Director, Government Printing and Stationery.

The Aga Khan Award for Architecture. 1995. Aranya Community Housing Report. Geneva: The Aga Khan Foundation.

Tyrwhitt, Jacqueline. 1947. Patrick Geddes in India. London: Lund Humphries.

Venturi, Robert. 1966. Complexity and Contradiction in Architecture. New York: The Museum of Modern Art. 